University of Nebraska - Lincoln

DigitalCommons@University of Nebraska - Lincoln

Agronomy \& Horticulture -- Faculty Publications

Agronomy and Horticulture Department

4-1928

Experimental Studies of Cultivation of Certain Vegetable Crops

J. E. Weaver

University of Nebraska-Lincoln

Follow this and additional works at: https://digitalcommons.unl.edu/agronomyfacpub

Part of the Plant Sciences Commons

Weaver, J. E., "Experimental Studies of Cultivation of Certain Vegetable Crops" (1928). Agronomy \& Horticulture -- Faculty Publications. 466.

https://digitalcommons.unl.edu/agronomyfacpub/466

This Article is brought to you for free and open access by the Agronomy and Horticulture Department at DigitalCommons@University of Nebraska - Lincoln. It has been accepted for inclusion in Agronomy \& Horticulture -Faculty Publications by an authorized administrator of DigitalCommons@University of Nebraska - Lincoln. 


\section{Experimental Studies of Cultivation of Certain Vegetable Crops}

For those who have an interest in the ecology of cultivated plants, Thompson's experimental studies on vegetable crops ${ }^{1}$ has a wealth of information. This memoir deals not only with the effect of cultivation on yield, but analyzes the several factors of soil moisture, soil temperature, and the production of nitrates as affected by cultivation, and the effect of weeds on these

1 Thompson, H. C. Experimental studies of cultivation of certain vegetable crops Cornell Univ. Agr. Exp. Sta., Mem. 107. 1927. 
factors. Finally the root habits are studied, and a correlation is made between the root system and the response of the plant to cultivation.

There is a prevailing impression among plant producers and writers of popular agricultural literature that the main benefit derived from cultivation is the conservation of moisture through the formation and maintenance of a soil mulch. Experimental evidence clearly shows that this is not the case and that the chief benefit derived from cultivation is through weed control. This conclusion, as regards field crops, has been reached as a result of extensive experiments (here briefly reviewed) chiefly on corn and cotton. One of these investigations, for example, ${ }^{2}$ was carried on in 28 states, through a period of seven years, and hence under a wide range of soils and climate. Weeds were kept down in the control plats by scraping the soil. No correlation was found between the rainfall and comparative yields from cultivated and uncultivated plats, nor between the yield per acre and the effect of cultivation as compared with scraping. An analysis of these results ${ }^{3}$ showed that the yields of corn were slightly larger on cultivated plats of clays and clay loams than on scraped ones but slightly less on silt loams and sandy loams.

Thompson's studies with vegetable crops are practically the first to be made in this field. He used several kinds of crops having different growth habits, viz: beets, carrots, onions, cabbage, celery, and tomatoes. The experiments were made on gravelly sandy loam at Ithaca, New York, and were continued for a period of six years.

The data on yield show conclusively that weed control was of much greater importance than the maintenance of a soil mulch. In fact carrots, cabbage, and tomatoes showed no significant increase in yield due to cultivation, as compared with scraping, and celery was the only crop of the six that showed large and consistent gains. Similar results with cabbage and also with lettuce have been obtained by the reviewer in eastern Nebraska. ${ }^{4}$ Where weeds were allowed to grow, Thompson found the effect of competition was to reduce the yields, sometimes as much as 80 per cent. It was also found that the soil mulch did not always result in the conservation of moisture, and in some instances resulted in its loss at critical periods, e.g., when the soil was cultivated soon after a light rain. Sometimes the mulch conserved moisture when a lower water content was an advantage to the crop. Hence the yield was not always larger even where the soil moisture was conserved by cultivation. Temperatures were slightly greater to 6 inches depth in the scraped plats, due to a more compact soil, but probably the differences were too small to appreciably affect yields. With one exception, differences in nitratenitrogen between the cultivated and scraped plats were not significant. Usually nitrates were slightly higher where the soil moisture was greater.

${ }^{2}$ Cates, J. S., and H. R. Cox. The weed factor in the cultivation of corn. U. S. Dept. Agr., Bur. Plant Ind., Bull. 257. I9I2.

${ }^{3}$ Mosier, J. G., and A. F. Gustafson. Soil moisture and tillage for corn. Ill. Agr. Exp. Sta., Bull. I8I. I9I5.

${ }^{4}$ Weaver, J. E., and W. E. Burner. Root development of vegetable crops. New York, McGraw-Hill. I927. 
"It does not seem probable that the injurious effects of weeds on crop yields are due entirely to their use of moisture and nutrient materials in the soil and to competition for light and air . . . some other factor, probably toxicity, is involved."

Studies of the root systems of the several crops were made at various times to determine the relation between the character and distribution of the roots, and the response of the crop to cultivation as compared with scraping. In general, as would be expected, those crops having the most widespread and best distributed root system were benefited least by the soil mulch. An examination of the photographs of the partially uncovered root systems shows why crops like celery and onions, whose roots do not spread so widely between the rows and would be less injured, are most benefited by cultivation. Furthermore, the fewer roots in the centers would intercept less water moving toward the surface when moisture is limited. "Under most conditions, if sufficient cultivation is given to keep the weeds from getting a start one need not concern himself about the soil mulch." The reviewer has repeatedly emphasized the fact again brought out by these studies that roots are abundant in the rich surface layers of soils, and that most of them will be destroyed if the soil is cultivated 3 or 4 inches deep. Hence it will be impossible for the plants to utilize the nutrients in this the richest portion of the substratum.

The extensive data are clearly summarized by means of graphs and tables. The 18 photographs on root distribution are excellent for their kind, but exhibit the difficulty of adequately showing root relations in this manner.

A study of this work illustrates the numerous problems that arise when the natural cover of vegetation is removed and crops are grown. In naturein prairies for example-it would seem that the roots of plants so thoroughly ramify the soil that, aside from the protecting covering afforded by the aboveground parts, little water is lost directly to the air. Nor does the problem of excessive fertility and too rank development to withstand drought enter. There is rarely or never an excess of nitrate-nitrogen in grasslands. "When the soil is warm and moist and plants are growing rapidly, nitrates are elaborated rapidly, but not excessively, and the plants thrive. As the soil becomes dry and the plants begin to suffer, nitrification diminishes also, and thus the plants are automatically saved from excessive nutriment in time of drought." ${ }^{5}$

The grower of crops may learn much by a study of the conditions under which natural vegetation is produced; the ecologist may likewise find many helpful suggestions by studying the problems of the practical plant producer. Thompson's research is an excellent example of the latter.

University of Nebraska,

J. E. WeAver LinCOLN, NeBr.

${ }^{5}$ Russel, J. C. Organic matter requirements of soils under various climatic conditions. Jour. Am. Soc. Agron., 19: 380-388. 1927. 